\title{
マンモグラフィで異常所見がなく 超音波のみ所見がある乳癌の特徵
}

博愛会相良病院乳腺科 ${ }^{11}$, 同病理細胞診診断部 ${ }^{21}$, 同画像診断部 ${ }^{3)}$

\begin{tabular}{|c|c|c|c|c|c|}
\hline 哲明 ${ }^{1)}$ & 相良 & 安昭 ${ }^{1)}$ & 大井 & 恭代 ${ }^{2)}$ & 久木田妙子 ${ }^{2)}$ \\
\hline 稔基 ${ }^{3)}$ & 相良 & 吉昭 ${ }^{1)}$ & 玉田 & 修吾 ${ }^{1)}$ & 馬場 信一 ${ }^{11}$ \\
\hline 義人 ${ }^{11}$ & 安藤 & 充嶽 ${ }^{1)}$ & 相扁 & 吉厚 ${ }^{1)}$ & \\
\hline
\end{tabular}

\begin{abstract}
2000 年 4 月より2007年 3 月までの 7 年間に手術された乳癌のうち術前 $M M G($ 二方向)か つUS 検査した2, 641例(全乳癌)を retrospective に分析し, MMGに異常所見がなくUS 検査が発見の契機となった乳癌(US乳癌)の特徵を全乳癌と比較し, US検診の可能性を 探つた。US乳癌は202例であり, 全乳癌の7 .6\%であった。年齢層別にみると全乳癌と比 較してUS乳癌は30歳代(11 .9\%vs7 5\%)と40歳代(39 1\%vs26 2\%)に多く，50歳代では 差がなく，60歳代70歳代では少なかった。全乳癌のうち非浸潤性乳管癌が占める割合は $12.4 \%$ に対し，US乳癌では32.7\%であった。浸潤癌のうち各組織亜型別の割合をみてみ ると, 通常型のうち乳頭腺管癌, 硬癌では差がなく, US 乳癌では充実腺管癌が少なかっ た(21.5\%vs8 4\%)。病理組織学的な浸潤径を測定した症例でみると，浸潤径が $1 \mathrm{~cm}$ 以 下の症例では全乳癌は17 3\%に対しUS乳癌は32 8\%であり, DCIS とT1を含めると全乳 癌は60 .0\%に対しUS乳癌は88 .9\%であった。

以上よりMMG では異常所見がないUS乳癌は若年者, 非浸潤癌と腫瘍径が小さい浸潤 癌が多かった。40歳代以下の若年者, 高濃度乳房の早期乳癌発見のためにはUS 併用は不 可欠であり，集団検診におけるUSの導入には早急に費用対効果の検討が必要と思われた。
\end{abstract}

Key words : 乳癌検診, 超音波検査, 乳房画像

\section{緒 言}

2001年の厚生労働省研究班によるがん検診の評 価判定では，50歳以上の視触診とマンモグラフィ (MMG)の併用による乳癌検診は十分な死亡減少 効果が認められ，40歳代では相応の根拠があり， 有効であると評価された。关れ以降40歳以上の女 性は隔年 1 回の M M G と触診による併用検診が 勧められてきた。しかし日本人乳癌の平均年齢は 欧米諸国より低く，当院のデータでは50歳未満は

\footnotetext{
別冊請求先 : ₹ 892-0833 鹿児島市松原町 3-31 博愛会相良病院乳腺外科 雷 哲明 E-mail address : thunders@sagara.or.jp
}

3 分の1を占め，また日本人女性，とくに閉経前 女性は高濃度乳房が多く，これら dense breast では乳癌が見落とされる可能性がある。乳癌は日 本人女性のがん罹患率の第1位を占め, 若年女性 は一般的に進行例，予後不良症例の頻度が高い。 しかも壮年年齢層にとってはまだ子供が小さく， 母親を乳癌で失うという悲劇は家庭にとっても社 会にとっても影響が大きいと思われる。幼い子供 を抱える母親のがん死亡はなんとしても避けた い。このような意味で超音波による早期乳癌発 見，ひいては乳癌死の減少の努力は急務である。

今回われわれはMMGで異常所見がなく, 超 音波でしか癌を発見できなかった症例を全乳癌症 例と比較してUS 乳癌の特徵を明らかにし, 超音 
波による乳癌検診の可能性を探った。

\section{1. 対象と方法}

2000年 4 月より2007年 3 月までの 7 年間当院で M MG(MLO +CC の二方向)かつUS を施行し, 穿刺吸引細胞診(FNA) または穿刺吸引組織診あ るいは open biopsy で確定診断後手術施行した乳 癌症例は2,641例であった(全乳癌)。このうち MMG で所見がなかった乳癌 (US 乳癌)は202例 (7 .6\%)であった。これらUS 発見乳癌を全乳癌 と比較し, 弚の特徵を明らかにする。

\section{2. 結 果}

\section{1)年齢分布}

全乳癌では20歳代18例(0.7\%)，30歳代197例 (7 5\%)，40歳代693例（262\%），50歳代739例
(28．0\%)，60歳代513例（19％％)，70歳代372例 (14 1\%)，80歳代94例(3 .6\%)，90歳代15例(0 .6\%) であり，30歳代と40歳代を併せると890例(33 .7\%) であった。

US 乳癌では20歳代 3 例(1 5\%)，30歳代24例 (11 .9\%)，40歳代79例（391\%），50歳代54例 （26.7\%），60歳代26例（12 .9\%），70歳代13例 (6 .4\%)，80歳代 3 例(1 .5\%)であり，30歳代と40 歳代を併せると103例(51 .0\%)であった(図 1)。

2)組織型 $(2003$ 年 5 月より 2007 年 3 月までの 1,699 例と比較)

全乳癌では非浸潤性乳管癌210例(12 4\%)，乳 頭腺管癌345例(20 3\%), 充実腺管癌366例(21 5 $\%$ ), 硬癌570例 (33.5\%), 光の他208例(12 2\%) であった。

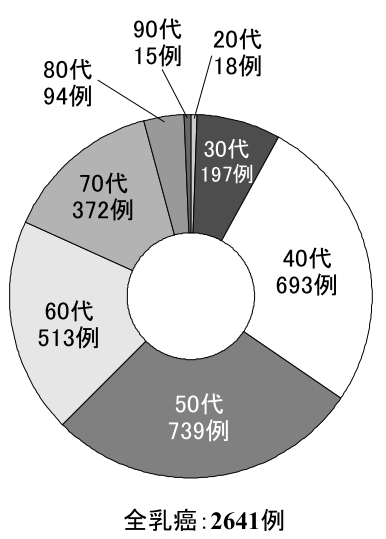

図 1. 全乳癌(右円グラフ)とUS 乳癌 (左円グラフ)の年齢分布

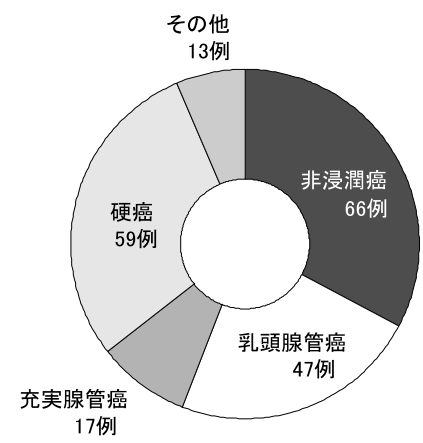

US乳癌: 202例

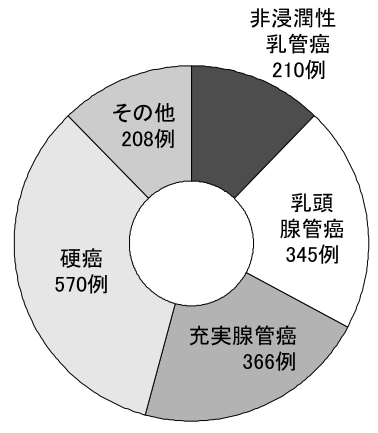

全乳癌: 1699例

図 2. 全乳癌(右円グラフ)とUS 乳癌(左円グラフ)の組織型 


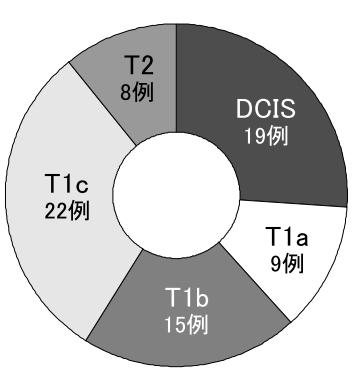

US乳癌: 73例

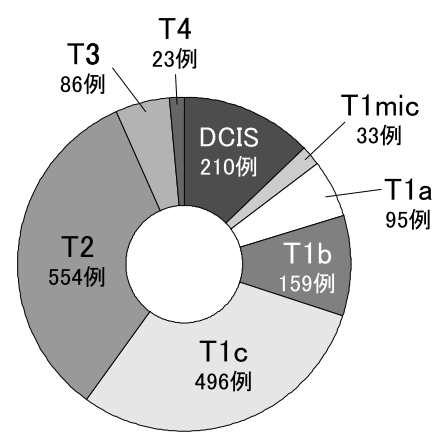

全乳癌: 1656例

図 3. 全乳癌(右円グラフ)とUS 乳癌(左円グラフ)の浸潤径

US 乳癌では DCIS 66例(32.7\%)，乳頭腺管癌 47例(23 3\%), 充実腺管癌17例(8 .4\%), 硬癌59 例(29 2\%)，关の他13例(6 4)であった。全乳癌 に比べUS乳癌は充実腺管癌の割合が少なく，光 の他の通常型では差がなかった(図 2)。

\section{3)浸潤径(上記症例のうち組織学的浸潤径を測定し た症例で比較)}

全乳癌のうち組織学的浸潤径を測定した1,656 例ではDCIS は210例(12.7\%), 微小浸潤(T1 mic) : 33例(2 .0\%), T1a : 95例(5.7\%), T1b : 159例(9 .6\%), T1c : 496例(30.0\%), T2 : 554例 (33 5\%) , T3 : 86例(5 2\%), T4 : 23例(1 4\%) であった。1 cm 以下(T1mic + T1 a + T1b)の浸潤 癌は17 $3 \%$ を占め, $2 \mathrm{~cm}$ 以下(T1)では47 $3 \%$ で あった。DCIS と浸潤径 $2 \mathrm{~cm}$ 以下の浸潤癌を含 むと60.0\%であった。

US 乳癌のうち組織学的な浸潤径を測定した73 例では，DCIS は19例 (26.0\%)，T1a： 9 例 (12 3\%)，T1b：15例（20 5\% ), T1c：22例 (30 1\%)，T2：8例(11 .0\%)であり，T3，T4の 症例はなかった。浸潤径 $1 \mathrm{~cm}$ 以下では32 8\%を 占め, $2 \mathrm{~cm}$ 以下(T1 )では62 .9\%であった。DCIS と浸潤径 $2 \mathrm{~cm}$ 以下の浸潤癌を含むと $88.9 \%$ であ つた(図 3)。

M M G では異常を指摘できなかった症例を 5 例 提示する(図 4 8)。

\section{3. 考 察}

マンモグラフィにおけるがん検出の感度は高濃 度乳房および若年者の dense breastでは著明に 低下することが知られている11。今回術前にMM G (二方向)かつUS を検査し，手術が行われた2,641 例を retrospective に調べた結果，MMGで異常を 指摘できずUSが発見の契機となった乳癌は202 例(7 .6\%)であった。同樣に愛知県がんセンター 中央病院の初治療乳癌928例での retrospective に MMG を見直した結果，70例(7 .5\%)に異常所見 がなかったとしており ${ }^{2)}$, われわれの今回の調べ とほぼ同じ頻度であった。これらの症例はMMG 単独検診では見逃されることになろう。US乳癌 を同時期の全乳癌症例と比較した結果，年齢層で はUS 乳癌は30歳代，40歳代に多く，50歳代では 変わらず,60歳代, 70歳代では少なかった。谷の 原因は30歳代, 40歳代は dense breastが多く, MMGでは写りにくいと考えられる。Dense breast は乳癌のリスクも高くなり，US を併用す るとがん発見率は上昇すると報告されている3 。 Corsetti ら"にによると，MMGで異常所見なしと された症例のうち36 5\%は dense breastに分類 され, dense breastにおけるUSの癌検出率は $0.44 \%$ と高かった。

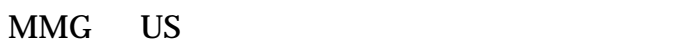
岡ら ${ }^{5}$ の多数症例の解析によると, 乳癌手術例の 

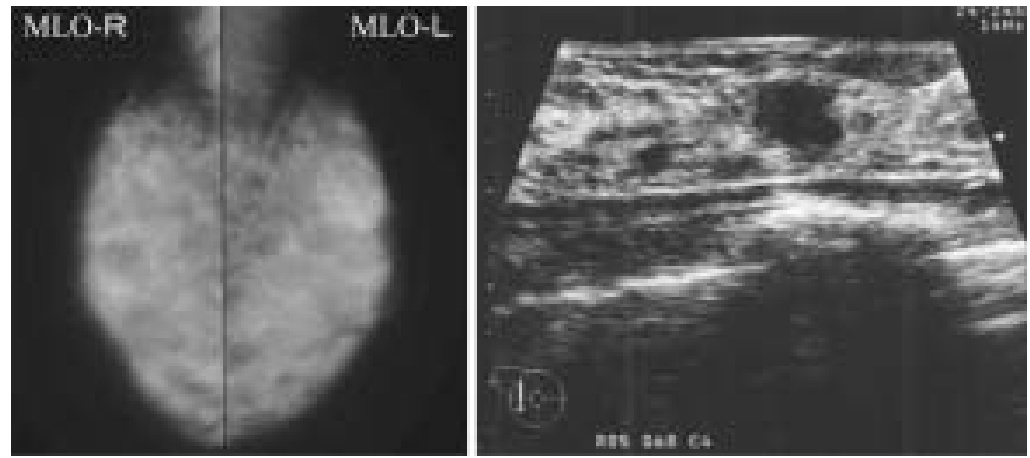

図 4. 症例 1：44歳. 主訴; 右腋窩違和感, 触診; 乳房, 腋窩に異常なく, MMG ; 異常を指摘できず.US : 右 CD に $7 \mathrm{~mm}$ 大の不整形低エコー腫 瘤, 手術標本では $8 \times 8 \mathrm{~mm}$ 大のDCIS を認めた .
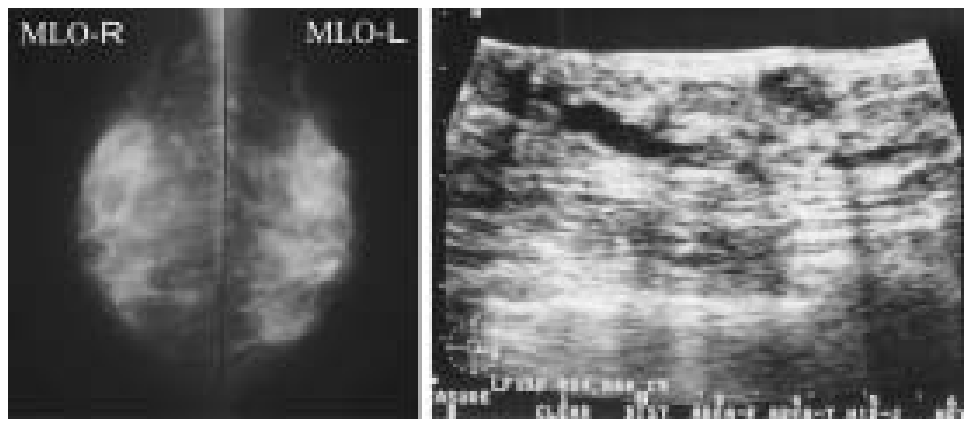

図 5. 症例 $2 ： 45$ 歳. 主訴; 左D の腫瘤(並存する線維腺腫), M M G ; 異常を認めず．US; 不規則な乳管拡張と壁在性腫瘤, 手術標本 ; 広がり $75 \times 13 \times 60 \mathrm{~mm}$ の DCIS.
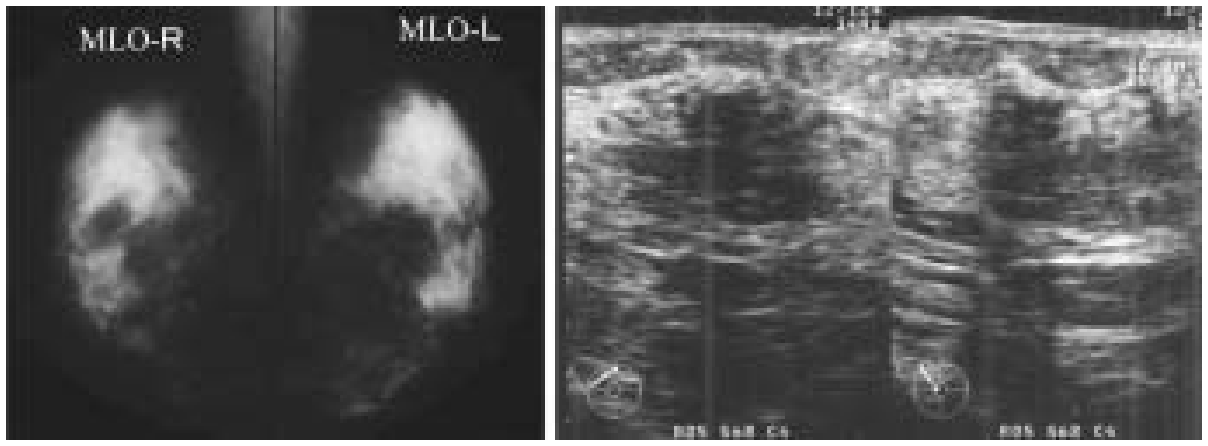

图 6. 症例 $3: 34$ 歳. 主訴; 右乳頭分泌, MMG; 不均一高濃度, 明らかな異常を指摘で きない.US; 不整形低エコー腫瘤, 手術標本病理; 乳頭腺管癌 . 広がり 60× 40× 25 $\mathrm{mm}, 2$ 15mm の多発浸潤巣を伴う.

うちMMGで所見が認められたのは901\%に対 し，USで所見が認められたのは97 5\%であり， 有意をもってUS は M M G より多くの症例で異常 所見が認められたとしている。年齢層別では低年
齢層ほどMMG で異常所見が認められなかった 症例が増え, また腫瘍径が小さくなるにつれて M M G での有所見率が低下するとしており ${ }^{5)}$ ，わ れわれの今回の調べと同樣の結果であった。 

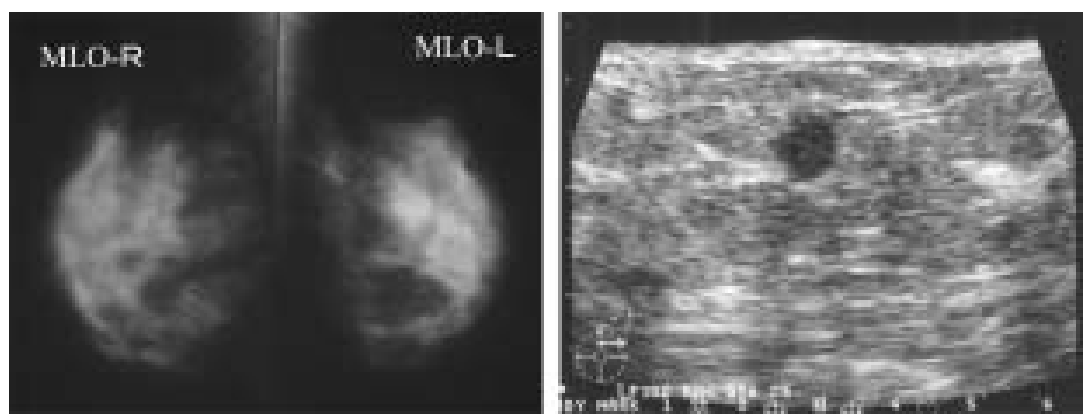

図 7. 症例 $4: 47$ 歳. 主訴; 左腋窩腫脹, MM ; 高濃度, 明らかな異常を指摘 できない.US；左 CにD/W 比の高い低エコー腫瘤，手術標本病理 ; 乳頭 腺管癌，広がり $80 \times 115 \times 30 \mathrm{~mm}$, 浸潤径； $7 \mathrm{~mm}$, リンパ節転移 2 個。
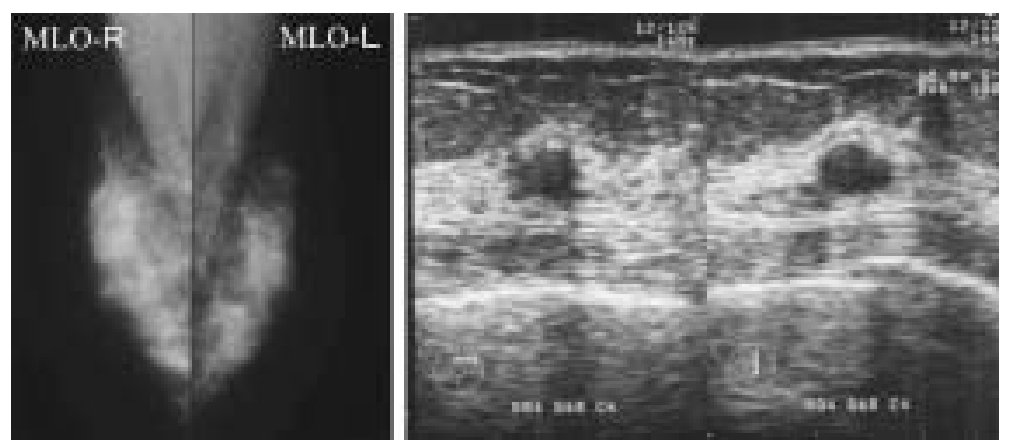

図 8. 症例 $5: 47$ 歳. 主訴; なし(検診希望), 触診; 異常なし, MMG ; 不均一高濃度, 明らかな異常を指摘できない.US ; 右 ACに $8 \times 5 \mathrm{~mm}$ の不整形低エコー腫瘤, 手術標本病理 ; 浸潤性小葉癌 , 広がり ; 40x $35 \times 10 \mathrm{~mm}$, 多発性浸潤巣を伴う。

一方，US 検査では線維腺腫，囊胞，いわゆる 乳腺症など多くの良性疾患が要精査の対象になり うるのも事実である゙。。このためにはUS要精査 基準》に従い，受診者の無用な不安をかき立てな いよう，また医療経済の観点からも明らかな良性 病変を安易に二次検診にまわすことは慎まなけれ ばならない。

乳癌死を減らすためにはまず検診受診率を増や さなければならない。弚のためには乳癌撲滅キャ ンペーンなどを通して受診率を上(げ)，さらに MMG では見逃されやすい乳癌を見つけるため， US 検査ではとくに小さい腫瘤, 囊胞内腫瘤, 扁 平低エコー像などに留意し, 非浸潤癌, 腫瘤径の 小さい乳癌の発見に努めれば乳癌死を減らすこと は可能と考えられる
本論文の要旨は第17回日本乳癌検診学会総会 (2007年11月21日, 横浜市)にて発表した

\section{【文 献】}

1) Kolb TM, Lichy J and Newhouse JH : Comparision of the performance of screening mammography, physical examination, and breast US and evaluation of factors that influence them: An analysis of 27,825 patient evaluations. Radiology 225 : 165-175, 2002

2 ) 水谷三浩, 高田英輝, 安藤由明, 他: 乳房超音 波検査の有用性。日本臨床，65(増刊号 6 ) : 298 $-303,2007$

3 ) Crystal P, Strano SD, and Shcharynski S, et al : Using sonography to screen women with mammographically dense breast. Am J Roentgenol, 
$181: 177-182,2003$

4 ) Corsetti V, Ferrari A, Ghirardi M, et al : Role of ultrasonography in detecting mammographically occult breast carcinoma in women with dense breasts. Radiol M ed, 111 : 440-448, 2006

5 ) 増岡秀次, 森満, 野村 直, 他: 乳癌検診 における超音波(US)の有用性について.日乳癌 検診学会誌, $16: 52-59,2007$

6 ) 相良安昭, 雷 哲明, 久木田妙子, 他: 乳癌検 診における超音波検査の有用性と検診導入への
問題点.日乳癌検診学会誌，15:221-226，2006

7 ) 角田博子 : 超音波検診における要精査基準 .日 乳癌検診学会誌, 13:83-87,2004

8 ) 中嶋啓雄, 陰山典男, 沢井清司, 他 : 京都府に 住む婦人のマンモグラフィ検診受診率を50\%に するプロジェクト．日乳癌検診学会誌，16:3843,2007

9 ) 佐久間浩: 超音波検診で乳癌死を減らすため に.日乳癌検診学会誌, $16: 74-78,2007$

\title{
Characteristics of Breast Cancer Detected by Sonography and Negative by Mammography
}

\author{
Yoshiaki Rai $^{1)}$, Yasuaki Sagara ${ }^{1)}$, Yasuyo Ooi $^{21}$, Taeko Kukita ${ }^{2)}$, Toshiki Taguchi' ${ }^{3)}$, Yoshiaki Sagara ${ }^{1)}$, \\ Syugo Tamada ${ }^{1)}$, Shinichi Baba ${ }^{1)}$, Yoshito Matsuyama ${ }^{1)}$, Mitsutake Ando ${ }^{1)}$, Yoshiatsu Sagara ${ }^{11}$
}

Divisions of B reast Surgery ${ }^{1)}$, Clinical Pathology ${ }^{2)}$, and B reast Imaging ${ }^{3)}$, Sagara H ospital

We conducted a retrospective review of 2,641 cases of breast cancer treated surgically between April 2000 and March 2007 for which both preoperative mammography (MLO and CC view) and sonography data were available. Among these cancers (overall BC) , 202(7 .6\%) were detected only by sonography, and were negative by mammography(US-BC). Analysis of age distribution showed that US-BC detected cancers more frequently in women in their thirties(11.9\% vs $7.5 \%)$ and forties ( $391 \%$ vs $262 \%$ ). Non-invasive ductal carcinoma was predominant among the US-BC cases, compared with overall BC (32.7\% vs $12.4 \%$ ). Invasive ductal carcinomas less than $1 \mathrm{~cm}$ in diameter were more prevalent among US-BC cases than among overall BC(32 8\% vs $173 \%$ ). DCIS and invasive ductal carcinomas less than $1 \mathrm{~cm}$ in diameter comprised $88.9 \%$ of US-BC cases, compared with $60 \%$ of overall BC. In conclusion, we suggest that sonography should carried out in addition to mammography in order to detect DCIS and early-stage cancer, particularly in women under 50 years old and those with dense breast tissue.

Key words : breast cancer detection, sonography, breast imaging 